\title{
High levels of genetic diversity and cryptic recombination is widespread in introduced Diplodia pinea populations
}

\author{
Wubetu Bihon $^{\dagger}$, Treena Burgess ${ }^{\dagger *}$, Bernard Slippers ${ }^{\dagger}$, Michael J. Wingfield ${ }^{\dagger}$ and Brenda D. \\ Wingfield $^{\dagger}$ \\ ${ }^{\dagger}$ Department of Genetics, Forestry and Agricultural Biotechnology Institute, University of Pretoria, Lunnon Road, \\ Hilcrest, Pretoria 0002, South Africa; \\ *School of Biological Sciences and Biotechnology, Murdoch University, Perth 6159, Australia.
}

Corresponding author: wubetu.bihon@fabi.up.ac.za

\begin{abstract}
Introduced populations of organisms typically have reduced diversity compared to those that are native. It is, therefore, unusual that introduced populations of the fungal tree pathogen Diplodia pinea have been shown to have high levels of genetic diversity, even surpassing diversity in some native regions. This is thought to be due to multiple introductions over time or the existence of a cryptic and yet undiscovered sexual cycle. In this study, we consider whether populations of $D$. pinea in Southern Hemisphere countries have similar patterns of diversity, share some level of genetic identity and how they might be influenced by sexual recombination. A total of 173 isolates from Argentina, Australia, Ethiopia and South Africa were characterized using 12 microsatellite markers. The results show that all these populations have high gene and genotype diversities, with the Australian population having the lowest diversity. Very few private alleles were found, suggesting that isolates from different countries might share a source
\end{abstract}


of introduction. However, based on allele distribution and frequency, each of the populations appeared to be evolving independently. The results showed that in all but the Australian population, alleles are randomly associated, suggesting that widespread sexual recombination has influenced population structure.

Keywords Diplodia pinea, Simple sequence repeat marker, Genetic diversity, Cryptic sex

\section{Introduction}

Diplodia pinea is a well-known pathogen of coniferous trees including more than 30 Pinus spp. worldwide (Swart et al. 1985; Palmer et al. 1987). The fungus was first reported in France in 1842 on diseased P. Sylvestris and has subsequently been found in most countries where Pinus spp. are grown (Swart and Wingfield 1991; Stanosz et al. 1999; Burgess et al. 2001a; Feci et al. 2003). Diplodia pinea is thought to have been moved around the world with pine planting stock most probably in its endophytic form as well as with seeds or seed lots contaminated with debris (Wingfield et al. 2001, Burgess and Wingfield 2002, Bihon et al. 2010). The introduced populations of $D$. pinea have been characterized in only a few instances (Smith et al. 2000; Burgess et al. 2001a, b, 2004). Consequently the history and possible connections between these introductions is poorly understood.

Knowledge of population dynamics of plant pathogens, including genetic diversity and modes of reproduction, allows for an understanding regarding the potential for evolutionary change (Nevo 1978; McDonald and McDermott 1993; McDonald 1997). Patterns of pathogen dispersal around the world and also within regions can be inferred from studying geographic distribution, structure and population diversity (Milgroom and Fry 1997; McDonald and Linde 
2002). Knowledge emerging from such studies can also indirectly contribute to the development of sound management strategies such as through the selection of resistant genotypes (McDonald and McDermott 1993; Burgess and Wingfield 2002; McDonald and Linde 2002).

Fungal plant pathogens are expected to be genetically more diverse in their native environments than where they are introduced (McDonald and McDermott 1993). This is due to a genetic bottleneck (Linde 2010) associated with the limited diversity of an introduction (Milgroom et al. 2008; Goss et al. 2009; Linde 2010). This is especially evident in asexual fungi or in sexually reproducing fungi where the absence of one mating type precludes genetic recombination (Goss et al. 2009). In contrast to this expectation, previous studies have shown that $D$. pinea is more diverse in its introduced range in South Africa than in a population from the USA, which is thought to be part of the native range of the pathogen (Burgess et al. 2004). This diversity is hypothesized to have originated from numerous introductions during the last 200 years probably on germplasm including seeds (Smith et al. 2000; Burgess and Wingfield 2002; Burgess et al. 2004). In contrast, Burgess et al. (2001a, 2004) found a much lower diversity in Australia compared with South Africa, and hypothesised that this was due to stricter quarantine restrictions and considerably fewer importations of plant material (Burgess et al. 2001a, 2004; Burgess and Wingfield 2002). To further complicate this issue, a recent study has suggested that the higher levels of diversity in South Africa could be linked to a cryptic sexual cycle (Bihon et al. 2011b).

While South African populations of D. pinea have been studied in detail, and Australian and New Zealand populations of the fungus to a lesser degree, no information is available regarding other introduced populations. The aim of this study was to consider whether the high levels of diversity and evidence for recombination is unique to the South African populations of 
D. pinea or whether this might also be true for other areas. To answer these questions, analyses using microsatellite markers were used to compare available collections of $D$. pinea isolates from Australia, South Africa, Ethiopia and Argentina.

\section{Materials and Methods}

\section{Isolation and isolates}

A total of 173 D. pinea isolates from Australia, South Africa, Ethiopia and Argentina were used in this study. Isolates from Western Australia $(\mathrm{N}=28)$ and Argentina $(\mathrm{N}=32)$ were obtained from the culture collection (CMW) of the Forestry and Agricultural Biotechnology Institute (FABI), University of Pretoria. Isolates from South Africa $(\mathrm{N}=56)$ were collected in the Boston area of the KwaZulu-Natal province. Those from Ethiopia $(\mathrm{N}=57)$ were collected in the Shashmene State Forest and the Wondogenet area. Isolation of the fungus was done using methods described previously (Bihon et al. 2011a).

\section{SSR-PCR and allele size determination}

DNA was extracted as described by Bihon et al. (2011a) and PCR amplification was conducted using twelve fluorescently labelled microsatellite primers as described previously (Burgess et al. 2001b; Bihon et al. 2011a). All amplifications were performed in $25 \mu$ l reaction volumes containing 1x PCR buffer (Roche Diagnostics) without $\mathrm{MgCl}_{2}, 2.5 \mathrm{mM} \mathrm{MgCl} 2,0.25 \mathrm{mM}$ each dNTPs (Fermantas, Nunningen, Switzerland), $0.2 \mathrm{mM}$ of each labelled forward (FAM, NED, PET, VIC) and reverse primers, $0.5 \mathrm{U}$ of Taq polymerase (FABI). Amplifications were assessed using agarose gel-electrophorosis and DNA was visualised with GelRed ${ }^{\mathrm{TM}}$ nucleic acid gel stain under UV light (Biotium, California). PCR products were diluted and multiplexed before 
separation on an ABI Prism 3100 genetic analyzer (Applied Biosystems) as described previously (Bihon et al. 2011a).

\section{Gene and genotype diversity}

The frequency of alleles at each locus and gene diversity $\left(\mathrm{h}^{*}\right)$ was calculated using the program POPGENE (Yeh et al. 1999). Genotypic diversity (G) was estimated using the equation $G=1 / \sum p i^{2}$ where $P i$ is the observed frequency of the $\mathrm{i}^{\text {th }}$ phenotype (Stoddart and Taylor 1988). In order to avoid bias arising from sample size, the genotypic diversity $(\mathrm{G})$ was divided by the value of the number of isolates to give maximum percentage genotype diversity $\left(G^{*}\right)$. Genotypic diversity was calculated for each population as $\mathrm{G}^{*}=\mathrm{G} / \mathrm{N}^{*} 100$, where $\mathrm{N}=$ number of isolates. Contingency chi-square $\left(\chi^{2}\right)$ tests for differences in allele frequencies were calculated for each locus across clone corrected populations. Gene diversities across loci were recorded as significantly different to one another when the calculated $\chi^{2}$ values were higher than the value on the chi-square table at $\mathrm{P}<0.05$ at each corresponding degrees of freedom.

\section{Linkage disequilibrium}

Random mating or sexual recombination was evaluated indirectly through analysis of Index of Association $\left(I_{A}\right)$ using the programme Multilocus 1.3 (Agapow and Burt 2000). In order to consider the effect of dependency of $I_{A}$ on number of loci, rbarD $\left(r^{-} D\right)$ was also analyzed using the same program. The observed $I_{A}$ and $r^{-} D$ values were compared with the output of 1000 times simulated random association of alleles. The null hypothesis $\left(H_{o}\right)$ that there is random association of loci was accepted when the observed values for $I_{A}$ were within the random data sets and probability $(\mathrm{P})$ values showed no significance difference at $\mathrm{P}<0.05$. 


\section{Divergence of populations}

Population differentiation, theta $(\theta)$ was analyzed between pairs of populations using Multilocus program (Agapow and Burt 2000) with an estimate of Wright's Fst for haploids as $\theta=\mathrm{Q}-\mathrm{q} / 1-\mathrm{q}$, where $\mathrm{Q}$ is the probability that two alleles from the same population are the same and $\mathrm{q}$ is the probability that two alleles from different populations are the same (Weir 1997). The alternative hypothesis that there is significant differentiation between populations was accepted when " $\theta$ " values were significantly different from the 1000 times randomized data sets at $\mathrm{P}<0.05$.

\section{Measure of genetic structure}

Population structure was inferred and assigned in STRUCTURE 2.2 (Pritchard et al. 2000) using 100,000 replicates of Monte Carlo Markov Chain (MCMC) analysis after an initial burn-in of 20,000 for $K$ ranging from 1 to 15 at 20 iterations. A Cluster identity of $>75 \%$ was used to assign clusters. In addition, analysis of molecular variance (AMOVA) in GenAlEx version 6.1 (Peakall and Smouse 2006) was carried out to differentiate percentage variations among and within populations.

\section{Results}

\section{SSR amplification}

Using the 12 SSR markers, 35 alleles were amplified for the 173 isolates representing the four populations of $D$. pinea isolates. Of these, one unique allele was observed in each of the Australian, Argentinean and Ethiopian populations. Four unique alleles were found in the South African population. The number of alleles observed for the populations ranged from 18 (Australia) to 24 (South Africa) (Table 1). For the 12 SSR markers used, 10 loci were 
polymorphic in the South African isolates while only seven loci were polymorphic in the Australia isolates. In the Argentina and Ethiopia populations, the same eight loci were polymorphic (Table 1).

Table 1. Comparison of $D$. pinea genotype diversity among four populations

\begin{tabular}{l|llllllll}
\hline Country & $\mathrm{N}$ & $\begin{array}{l}\text { No of } \\
\text { haplotypes }- \\
\text { symbol }\end{array}$ & $\begin{array}{l}\text { Polymorphic } \\
\text { loci }\end{array}$ & Alleles & $\begin{array}{l}\text { Unique } \\
\text { alleles }\end{array}$ & $\mathrm{G}^{*}$ & $I_{A}$ & $r^{*} D$ \\
\hline Australia & 28 & 10 & 7 & 18 & 1 & 13.861 & $0.939^{*}$ & $0.237^{*}$ \\
Argentina & 32 & 20 & 8 & 21 & 1 & 40.000 & $0.091^{\mathrm{NS}}$ & $0.013^{\mathrm{NS}}$ \\
Ethiopia & 57 & 24 & 8 & 21 & 1 & 24.464 & $0.009^{\mathrm{NS}}$ & $0.001^{\mathrm{NS}}$ \\
RSA & 56 & 33 & 10 & 24 & 4 & 43.75 & $-0.047^{\mathrm{NS}}$ & $-0.005^{\mathrm{NS}}$ \\
\hline
\end{tabular}

$\mathrm{N}=$ total number of isolates, $\mathrm{G}^{*}=$ maximum percentage genotype diversity, RSA = Republic of South Africa, ${ }^{*} \mathrm{P}$ value $<0.05$ indicating significant linkage disequilibrium and NS $=$ non significance differences.

\section{Gene and Genotype diversity}

Mean gene diversity across all loci ranged from 0.105 for the Australia collection to 0.293 in the Argentina population (Table 2). The highest level of genotype diversity was observed for the South African (43\%) and Argentinean (40\%) isolates. Only, moderate diversity was found for the Ethiopian isolates (23\%) and the Australian isolates exhibited the lowest (13\%) diversity (Table 1). However, in its native environment in eastern USA and Canada the genotype diversity of D. pinea was $27 \%$ (Burgess et al. 2004). Chi-square tests for the clone corrected populations showed significant differences $(\mathrm{P}<0.05)$ in gene diversities at each of the loci. This was influenced by the monomorphic loci and unique alleles. 
Table 2. Gene diversity and chi-square $\left(\square^{\square} \square \square\right.$ tests for differences in allele frequencies for 12 SSR loci across clone corrected populations of $D$. pinea

\begin{tabular}{l|llllll}
\hline Locus & Australia & Argentina & Ethiopia & RSA & $\square^{\square}$ & df \\
\hline SS1 & 0.000 & 0.498 & 0.289 & 0.057 & $97.62^{* * *}$ & 6 \\
SS2 & 0.133 & 0.498 & 0.000 & 0.291 & $19.64^{* * *}$ & 3 \\
SS7 & 0.000 & 0.000 & 0.000 & 0.359 & $16.34^{* * *}$ & 3 \\
SS8 & 0.245 & 0.375 & 0.388 & 0.208 & $14.70^{* *}$ & 6 \\
SS9 & 0.337 & 0.482 & 0.035 & 0.327 & $51.91^{* * *}$ & 6 \\
SS10 & 0.000 & 0.506 & 0.499 & 0.535 & $76.82^{* * *}$ & 9 \\
SS11 & 0.294 & 0.000 & 0.495 & 0.057 & $92.39^{* * *}$ & 6 \\
SS12 & 0.131 & 0.305 & 0.352 & 0.057 & $38.35^{* * *}$ & 6 \\
SS13 & 0.000 & 0.000 & 0.216 & 0.000 & $53.54^{* * *}$ & 8 \\
SS14 & 0.000 & 0.375 & 0.100 & 0.113 & $58.79^{* * *}$ & 6 \\
SS15 & 0.131 & 0.471 & 0.000 & 0.291 & $15.46^{* *}$ & 4 \\
SS16 & 0.000 & 0.000 & 0.000 & 0.251 & $16.17^{*}$ & 6 \\
\hline Mean & 0.105 & 0.293 & 0.198 & 0.212 & & \\
\hline df $=$ degree of freedom (number of populations -1$)($ number of alleles -1$)$. \\
$*^{* * *}{ }^{* * *}$ indicates significance differences at P $<0.05,0.01$ and 0.001 respectively.
\end{tabular}

\section{Linkage disequilibrium}

Linkage disequilibrium was analysed to evaluate the potential of random mating within the different populations. The $I_{A}$ and $r^{-} D$ values for all the populations showed that there were no significant differences between the observed and randomized data-sets for the populations from South Africa, Ethiopia and Argentina. In these populations, the observed $I_{A}$ and $r^{-} D$ values fell inside the distribution for randomized data sets. In contrast, significant differences were found between the observed and randomized data sets for the Australian population (Table 1) and when the combined data set was analysed $\left(I_{A}=0.818, \mathrm{P}<0.001\right)$. Therefore, the null hypothesis that loci are randomly associated in the populations from South Africa, Argentina and Ethiopia was accepted. The hypothesis of random association could, however, not be accepted for the Australian population. 


\section{Genetic structure and variation}

Analysis of molecular variance confirmed that there was a significant percentage of variation among and within populations responsible for the total variation. Forty two and fifty eight percent of the total molecular variance was accounted for among and within populations, respectively. Pair-wise population differentiation was also significantly different between each population (Table 3). AMOVA analyses showed that percentage of genetic variation among individuals within populations was $58 \%$ and that the variation among populations was $42 \%$. Analysis using STRUCTURE showed that genotypes grouped based on geographic origin of the isolates but there was a high level of admixture in the South African and Ethiopian populations (Fig. 1).

Table 3.Pairwise comparisons of population differentiations $(\Theta)$ among $D$. pinea populations from different countries in the world

\begin{tabular}{l|rrl}
\hline & Argentina & Ethiopia & RSA \\
\hline Australia & $0.465^{* * *}$ & $0.683^{* * *}$ & $0.515^{* * *}$ \\
Argentina & - & $0.616^{* * *}$ & $0.369^{* * *}$ \\
Ethiopia & \multicolumn{2}{|c}{-} & $0.609^{* * *}$ \\
\hline
\end{tabular}

\footnotetext{
Population are significant different from each other at $\mathrm{P}<0.001$.
}

Figure 1. Genotype by STRUCTURE 2.2 revealed four underlying groups of probability of affiliation on the bases of the geographical sources of isolates. Differences in colour within a vertical bar indicate a multi-population affiliation of an individual genotype. The height of each colour within an individual is the measure of proportional affiliation.

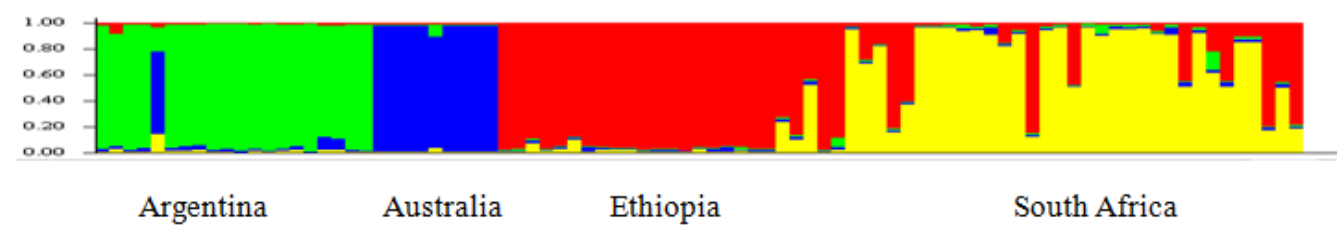




\section{Discussion}

Analysis of four introduced D. pinea populations from South Africa, Ethiopia, Argentina and Australia, using microsatellite markers, showed that diversity was moderate to high in populations of the fungus from all countries other than Australia. Strong evidence also emerged to suggest that recombination has occurred in this fungus in these three countries. These data support previous findings for the pathogen in South Africa, where diversity was unexpectedly high (Smith et al. 2000; Burgess et al. 2001a; Burgess et al. 2004). Results of the present study added Ethiopian and Argentinean populations of $D$. pinea and unlike the previous study of Burgess et al. (2004), the South African isolates were specifically collected from a single area to prevent confusion arising from possible multiple introductions of the fungus into different areas. Diversity was low in the Australian population, which has previously been shown to have benefited from strong quarantine measures (Burgess et al. 2001a; Burgess and Wingfield 2002; Burgess et al. 2004) and there was no evidence of recombination in that population.

High levels of genotypic diversity in the South African D. pinea population were consistent with findings in previous studies where the introduced population was more diverse than that seen in native pine forests of USA, Europe and Indonesia (Smith et al. 2000; Burgess et al. 2001a; Burgess et al. 2004). In those studies, the data were interpreted as reflecting introductions of multiple genotypes over time. What was different in the present study is the fact that all the isolates were collected from a single area, which would dispel the possibility of different introductions into the same areas. An alternative explanation for the high level of genotypic diversity in the South African, Ethiopian and Argentinean populations in this study is that genotypic diversity increases due to out-crossing over time. This is the most plausible explanation for the results and it suggests that there is cryptic sexual recombination in $D$. pinea 
in these countries. Although mutation can increase genetic diversity, this is unlikely to be relevant because very few private alleles were found in the different populations (Halliburton 2004).

Diplodia pinea has always been thought to reproduce only asexually (Sutton 1980; Burgess et al. 2004), but a recent study confirmed that recombination of alleles occurs in the South African populations of this fungus (Bihon et al. 2011b). The present study provides evidence to suggest that recombination is a widespread phenomenon in D. pinea populations. Linkage disequilibrium analysis showed that $D$. pinea populations from South Africa, Ethiopia and Argentina were not significantly different from the randomized hypothetical data sets, thus providing evidence for recombination. The application of $I_{A}$ values to infer the possibility of random association of genotypes due to cryptic sex is an approach that has been used for many other studies on fungi (Geiser et al. 1994, Kohli and Kohn 1998, Morgan et al. 2007, Groenewald et al. 2008).

Recombination in fungi for which there is no known sexual state is well recognised. For example Aspergillus nidulans (Geiser et al. 1994), Fusarium oxysporum, Alternaria alternata (Arie et al. 2000) and Cercospora beticola (Groenewald et al. 2008) are asexual fungi in which cryptic recombination has been noted. This is thought to emerge from a sexual state that has not yet been discovered or from a parasexual cycle (Taylor et al. 1999). Population genetic studies can provide evidence for occurrence of cryptic sex in filamentous fungi in which sexual reproduction has not been previously reported (Kuck and Poggeler 2009) as has emerged in this study. Sexual structures typically occur in nature and can be very difficult to locate. Although some effort has been made to find these structures for D. pinea (Wingfield, unpublished), it is 
entirely possible that they are present. The presence of spermatia in cultures of D. pinea (Wingfield and Knox-Davies 1980) also suggests that a sexual state occurs in this fungus.

An interesting aspect of the results of this study is that there was significant geographic structure to the populations. This is based on distribution and frequency of different alleles. Yet most alleles were shared between the populations and very few private alleles occurred in each population. It is consequently possible that these could have arisen from mutation (Zhan and McDonald 2004). This implies that introductions into countries such as South Africa, Australia and Ethiopia might have originated from a common source or sources, and that there has been limited exchange between the regions other than in the case of the Argentinean population that was distantly related to other populations. Mutation, probably at a limited level, and recombination has most likely further added to the differentiation of the populations since they were first introduced into the respective regions.

A recent study has shown that substructure in $D$. pinea population occurs even over relatively small geographic distances (Bihon et al. 2011b). It has also been shown that the potential of $D$. pinea to be distributed via seed is very low (Bihon et al. 2010) and the fungus is not insect-vectored. Limited long distance dispersal, geographical barriers and reproductive isolation between populations should, therefore, lead to isolated populations that are differentiated from each other. Given the geographical distance between the populations considered in this study, natural spread would thus not be expected to influence gene flow.

The genetic distance between isolates from Argentina and the other three populations was high while the South Africa, Ethiopia and Australia populations were relatively closely related. There was evidence of genetic admixture, especially among South African and Ethiopian populations although this was not supported by the analysis of population differentiation. These 
admixtures could be due to the fact that pine germplasm has been shared between South Africa and Australia as suggested by Burgess and Wingfield (2002). It is not known whether plant material has been exchanged between South Africa and Ethiopia, but this is very likely given the very long history of forestry and domestication of Pinus spp. in South Africa. This would also be consistent with the fact that South Africa has provided a source for forestry planting stock for many African countries and there is evidence that pathogens have also moved with this material (Hunter et al. 2008).

Movement of planting stock between countries is clearly contributing to pathogen introductions and every effort must be made to reduce this trend (Wingfield et al. 2001, 2008). The results of this study have also shown that cryptic recombination is a widespread phenomenon in most of the introduced $D$. pinea populations. Natural recombination can occur between different genotypes of well-known pathogens such as D. pinea (Zwolinski et al. 1990) and it is necessary to also recognise the dangers not only of introducing new pathogens, but also genotypes of pathogens already present in countries.

\section{Acknowledgements}

This research was financially supported by the DST/NRF Centre of Excellence in Tree Health Biotechnology (CTHB), members of the Tree Protection Co-operative Program (TPCP) and the International Foundation for Sciences, Stockholm, Sweden, through a grant to Wubetu Bihon.

\section{References}

Agapow PM, Burt A (2000) 'Multilocus 1.2' (Department of Biology, Imperial College: Ascot, UK). 
Arie T, Kaneko I, Yoshida T, Noguchi M, Nomura Y, Yamaguchi I (2000) Mating-type genes from asexual phytopathogenic ascomycets Fusarium oxysprum and Alternaria alternata. Mol Plant Microbe In 13: 1330-1339.

Bihon W, Burgess T, Slippers B, MJ Wingfield, BD Wingfield (2011a) Distribution of D. pinea and its genotypic diversity within asymptomatic P. patula trees. Australas Plant Pathol, doi 10.1007/s13313-011-0060-z.

Bihon W, Slippers B, Burgess T, MJ Wingfield, BD Wingfield (2011b) Diverse sources of infection and cryptic recombination revealed in South African Diplodia pinea populations. Fungal Biol (submitted).

Bihon W, Slippers B, Burgess T, Wingfield MJ, Wingfield BD (2010) Sources of Diplodia pinea endophytic infections in Pinus patula and P. radiata seedlings in South Africa. For Pathol, doi 10.1111/j.1439-0329.2010.00691.x.

Burgess T, Wingfield BD, Wingfield MJ (2001a) Comparison of genotypic diversity in native and introduced populations of Sphaeropsis sapinea isolated from Pinus radiata. Mycol Res 105: $1331-1339$.

Burgess T, Wingfield MJ, Wingfield BD (2001b) Simple sequence repeat markers distinguished among morphotypes of Sphaeropsis sapinea. Appl Environ Microbiol 67: 354-362.

Burgess TI, Wingfield MJ (2002) Quarantine is important in restricting the spread of exotic seed-borne tree pathogens in the southern hemisphere. Int Forest Rev 4:56-65.

Burgess T, Wingfield MJ, Wingfield BD (2004) Global distribution of Diplodia pinea genotypes revealed using simple sequence repeat (SSR) markers. Australas Plant Pathol 33: 513-519.

Feci E, Smith D, Stanosz DR (2003) Association of Sphaeropsis sapinea with insect-damaged red pine shoots and cones. For Pathol 33: 7-13.

Geiser DM, Arnold ML, Timberlake WE (1994) Sexual origins of British Aspergillus nidulans isolates. Proc Natl Acad Sci USA 91: 2349-2352. 
Goss EM, Larsen M, Chastagner GA, Givens DR, Grunwald NJ (2009) Population genetic analysis infers migration pathways of Phytophthora ramorum in US nurseries. PLoS Pathog 5: e1000583, doi:10.1371/journal.ppat.1000583.

Groenewald M, Linde CC, Groenewald JZ, Crous PW (2008) Indirect evidence for sexual reproduction in Cercospora beticola populations from sugar beet. Plant Pathol 57: 25-32.

Halliburton R (2004) Introduction to population genetics. Pearson Education, Inc., USA.

Hunter GC, van der Merwe NA, Burgess TI, Carnegie AJ, Wingfield BD, Crous PW, Wingfield MJ (2008) Global movement and population biology of Mycosphaerella nubilosa infecting leaves of cold-tolerant Eucalyptus globulus and E. nitens. Plant Pathol 57: 235-242.

Kohli Y, Kohn LM (1998) Random association among alleles in clonal populations of Sclerotinia sclerotiorum. Fungal Genet Biol 23: 139-149.

Kuck U, Poggeler S (2009) Cryptic sex in fungi. Fungal Biol Rev 23: 86-90.

Linde CC (2010) Population genetic analyses of plant pathogens: new challenges and opportunities. Australas Plant Pathol 39: 23-28.

McDonald BA (1997) The Population Genetics of Fungi: Tools and Techniques. Phytopathology 87: $448-453$.

McDonald BA, Linde C (2002) Pathogen population genetics, evolutionary potential and durable resistance. Annu Rev Phytopathol 40: 349-379.

McDonald BA, McDermott JM (1993) Population Genetics of Plant Pathogenic Fungi: Electrophoretic markers give unprecedented precision to analyses of genetic structure of populations. BioScience 43: $311-319$.

Milgroom MG, Fry WE (1997) Contributions of population genetics to plant disease epidemiology and management. Adv Bot Res 24: 1-30.

Milgroom MG, Sotirovski K, Spica D, Davis JE, Brewer MT, Milev M, Cortesi P (2008) Clonal population structure of the chestnut blight fungus in expanding ranges in south eastern Europe. Mol Ecol 17: 4446-4458. 
Morgan JAT, Vredenburg VT, Rachowicz LJ, Knapp RA, Stice MJ, Tunstall REB, Parker JM, Longcore JE, Moitz C, Briggs CJ, Taylor JW (2007) Population genetics of the from-killing fungus Batrachochytrium dendrobatidis. Proc Natl Acad Sci USA 104: 13845-13850.

Nevo E (1978) Genetic Variation in Natural Populations: Patterns and Theory. Theor Popul Biol 13: 121177.

Palmer MA, Stewart EL, Wingfield MJ (1987) Variation among isolates of Sphaeropsis sapinea in the north central United States. Phytopathology 77: 944-948.

Peakall R, Smouse PE (2006) GENALEX 6: Genetic analysis in Excel. Population genetic software for teaching and research. Mol Ecol Notes 6: 288-295.

Pritchard JK, Stephens M, Donnelly P (2000) Inference of population structure using multilocus genotype data. Genetics 155: 945-959.

Smith H, Wingfield MJ, de Wet J, Coutinho TA (2000) Genotypic diversity of Sphaeropsis sapinea from South Africa and Northern Sumatra. Plant Dis 84: 139-142.

Stanosz GR, Swart WJ, Smith DR (1999) RAPD marker and isozyme characterization of Sphaeropsis sapinea from diverse coniferous hosts and locations. Mycol Res 103: 1193-1202.

Stoddart JA, Taylor JF (1988) Genotype diversity: Estimation and prediction in samples. Genetics 118: $705-711$.

Sutton BC (1980) The Coelomycetes. Commonwealth Mycological Institute, Kew, Surrey, England.

Swart WJ, Knox-Davis PS, Wingfield MJ (1985) Sphaeiopsis sapinea, with special reference to its occurrence on Pinus spp. in South Africa. S Afr For J 35: 1-8.

Swart WJ, Wingfield MJ (1991) Biology and control of Sphaeropsis sapinea on Pinus species in South Africa. Plant Dis 75: 761-766.

Taylor JW, Jacobson DJ, Fisher MC (1999) The evolution of asexual fungi: reproduction, speciation and classification. Annu Rev Phytopathol 37: 197-246.

Weir BS (1997) Genetic data analysis II. Sinauer Associates Inc.: Sunderland, MA. 
Wingfield MJ and Knox-Davies PS (1980) Association of Diplodia pinea with a root disease of pines in South Africa. Plant Dis 64: 22-223.

Wingfield MJ, Slippers B, Roux J, Wingfield BD (2001) Worldwide Movement of Exotic Forest Fungi, Especially in the Tropics and the Southern Hemisphere. BioScience 51: 134-140.

Wingfield MJ, Slippers B, Hurley BP, Coutinho TA, Wingfield BD, Roux J (2008) Eucalypt pests and diseases: growing threats to plantation productivity. Southern Forests 70: 139-144.

Yeh FC, Yang RC, Boyle T (1999) POPEGENE version 1.31 (Microsoft windows based freeware for population genetic analysis. Alberta).

Zhan J, McDonald BA (2004) The interaction among evolutionary forces in the pathogenic fungus Mycosphaerella graminicola. Fungal Genet Biol 41: 590-599.

Zwolinski JB, Swart WJ, Wingfield MJ (1990) Economic impact of a post-hail outbreak of dieback induced by Sphaeropsis sapinea. Eur J Forest Pathol 20: 405-411. 